\title{
The role of the economic and behavioral circumstances in the IAS/IFRS's adoption (the case of developing countries)
}

\author{
Olfa Riahi $^{1 *}$, Walid Khoufi ${ }^{2}$ \\ ${ }^{1}$ PhD student at the Faculty of Economics and Management of Sfax-Tunisia \\ ${ }^{2}$ Lecturer at the Institute of Business Studies of Sfax-Tunisia \\ *Corresponding author E-mail: olfa-riahi@hotmail.com
}

\begin{abstract}
In this paper, we suggest to study the impact of economic and behavioral factors on the decision to adopt IFRS in developing countries until the year 2013.By using the accounting approach of "institutional -environment" determinism and based on a sample of 76 developing countries. This work has allowed us to conclude that behavioral factors, mainly corruption, influence more than economic factors the decision of adopting or not IFRS by developing countries.
\end{abstract}

Keywords: International Accounting Standards (IAS / IFRS); Developing Countries; “Institutional-Environment” Determinism.

\section{Introduction}

The internationalization of trade and the globalization of companies are on the ascendant. The financial statements prepared in accordance with local accounting systems could therefore, hardly gather the needs of investors and business partners and. To bridge the gap in accounting practices between countries, the International Accounting Standards Committee (IASC) founded in 1973 by a group of accountants, has supported the attempt to formulate a uniform accounting standard that would aim to reduce the international accounting gaps.

Consequently, the International Accounting Standards (IAS) has been proposed. These were always the "champions" of uniformity and standardization of accounting principles for more than two decades (Carlson, 1997). In April 2001, the International Accounting Standards Board (IASB) took over the establishment of accounting standards developed by the International Accounting Standards (IASC) by updating existing (IAS) to finally appoint the International Financial Reporting Standards (IFRS). More than 140 countries have now decided to adopt IFRS for financial reporting. Therefore, all European companies listed on European stock markets have made use of IFRS since January 2005. Canada and Japan have adopted IFRS in 2011.

While developed countries have largely been entered into the movement of the development of accounting systems that reflect the attributes of their environment, developing countries seem to be submissive to the adoption of these systems which were invented to more developed circumstances. During this time, the markets of developing countries are the target of the main industries of the world operating in saturated western countries. To better perform their activities in these countries, an adoption of appropriate accounting standards will be essential. This appears to be absurd in so far as it is commonly accepted that the accounting practices cannot be developed in isolation, but should rather take into account the specific environment in which they run. Accord ing to this perspective of analysis, it is possible to say that developing countries have adopted standards and accounting principles that are not necessarily related to their national heritage. These concretize the interference of the environment in these countries (Hussein and Al. 2002). Therefore, and in our opinion, the accounting standards in most developing countries do not detect a case in a perfect harmony with the reality of a nation. It usually results from a search for legitimacy on the part of those states in the international community. This can predict that, specifically, the behavioral component that has the key role in the adoption of IFRS by these countries. This research is pushed, firstly, by the desire to discern why some developing countries are still far from adopting IFRS despite the latter leading to the improvement of the quality of financial reporting, comparability, reliability and the relevance of financial statements, and secondly by the scarcity of researches that have addressed this issue in the context of these countries. It should be noted that most previous studies are normative in the description of the position of a particular country in applying international accounting standards (Zeghal and Mhedhbi, 2006).At the present study, we strive to provide input to the oriented prior literature on the determinants of the choice of an accounting practice by developing countries through their impact to a new dimension which is the behavioral attributes. The rest of this paper is structured as follows: the second section will strive to expose the background and hypotheses of the research. The third section presents the methodology. The fourth section will focus on the synthesis of the main empirical findings. Finally, in the fifth section, we present our main conclusions.

\section{Background and hypothesis development}

To study and scope the impact of some factors on the adoption of IFRS, it is important to have basically a theoretical framework supported in the analysis of the effects of different environmental factors on the adoption of accounting practices. Our study will focus only on economic and behavioral factors. Epistemologically, 
the conceptual framework of our research will be part of a descriptive perspective of different research studies, which have applied to the study of the impacts of economic and behavioral factors on the adoption of international accounting standards by developing countries. Empirical researches on the favorable and unfavorable factors to the adoption of IFRS are uncommon. First, most of the few existing studies are normative in the explanation of the position of a particular country in applying international accounting standards. On the other hand, the comparability of accounting systems are becoming a popular research. This is achieved through the concentration of research on conceptual and / or empirical specification, economic explanations, political, social, cultural and historical background of any nation. The adoption's movements of an accounting system centered on evolutionary and complex principles pushes us to go beyond the traditional normative theories of accounting as they do not hold the actual practices to ascertain their assertions. To this end, we call for an integrative theory to explain the mechanism of IFRS adoption in developing countries: the environment and institutional determinism theory. However, this theory has appealed to other theories in the exploratory discovery, reasoning process or invention, namely the agency theory, neo-institutional theory and the theory of planned behavior. The theory of environmental and institutional determinism will be considered, therefore, as a motive in our research. It appears that the simple definition of an environment-institutional determinism is that the environment is responsible for all human actions. In other words, the environment and institutional determinism assume the importance of the situation in all company's initiatives This school of thought supports the consideration of the environment in any kind of strategic analysis. Indeed, the relationship between the environment and the firm is a supreme element of the strategic management theories (Bamberger, 1988; Ginsberg and Venkatraman, 1985). Under the contingency theory, the environment will affect the organizational structure of the company, but we can stare that its impacts will be more compromising. Deterministic school with different scopes (Lawrence and Lorsch, 1967; Hannan and Freeman, 1977; Miller, 1986; Mintzberg, 1989) is channeled on the idea that for a particular, environment requires a particular strategy (Hambrick and Lei, 1985). This vision was founded in industrial economics theory (Porter, 1980) for which a set of exogenous forces; the firm will determine the rate of profit and the type of adoption's strategy. Consequently, the theory of environmental-institutional determinism which suggests a positive relationship between accounting and its environment, (Mueller 1967; Mueller, 1968; Seidler 1967 Previts 1975 Radebaugh 1975; Choi and Mueller, 1984; DaCosta and all. 1978; Frank 1979; Nair and Frank 1980; Belkaoui 1983 Belkaoui and Maksy 1985) showed indirect evidence in favor of the environment that influences the selection of accounting regulations.

Since the creation of the IASB, the Committee has issued 41 standards and a number of exposure drafts that are intended to guide accounting on the preparation of financial statements. Various criticisms on these standards resulted in a large body of literature on the subject, including many studies on the relevance of standards for developing economies (Mir and Rahamen, 2004). In addition, there are studies (e.g. Nigeria, Ghana) have explored the relevance and importance of IFRS in specific geographic contexts. A common view among these studies is recommended to change these international accounting standards to match local environmental conditions (Hassan, 1998; Al-Rai Dahmash, 1998 Mirghani, 1998; Larson, 1993; Enthoven 1973).Other Other studies have criticized the role of occidental countries and donor agencies in the increasing attempts to put pressure on developing countries to adopt international accounting standards (Hassan, 1998; Points and Cunningham, 1998; Wallace and Briston, 1993; Perera, 1989; Samuels, 1990; Briston, 1990 Samuel and Oliga 1982). In the literature, confirming or invalidating the importance of environmental factors on the development of the accounting system of a country, the studies are generally descriptive. However, a rare effort was concerned through a quantifiable epistemology to discern the interdependence of factors that took into account differ- ences in the accounting systems of the country. In this respect, our reading of the English and French studies since the sixties showed that research on environmental factors accounting has plenty emerged ink.

To achieve this, various studies were sometimes designed by explaining many environmental factors that affect accounting systems, and other times only one influencing factor. The glimpse which inflicts throughout the literature during the review of the various factors that promotes the adoption of IFRS are first, that the majority of studies are mainly interested in the cultural factor and other factors and secondly, that most researchers are involved in the effect of the environment on the accounts in several countries (Hassab et al, 2003). It appears that the international accounting literature generally supports that accounting is largely influenced by the environment found in different countries. Alhashim and Arpan (1992) showed that the most predominant environmental factors influencing accounting are economic strength, social forces, the legal system and culture. In fact, a majority of the literature highlighted the importance of factors of an institutional nature (economic growth, level of education, capital markets). In the process of economies opening, societal mutations play a fatal role with outcomes on the different environmental factors accounting, such as politics, economics, culture, etc., It must be said that the accounting doctrines of many countries are under relentless pressure of several factors, including economic, political and social.

To develop and oversee our hypothesis, we will appeal mainly to literature that analyses the relation could be established between the evolution of the accounting system of a country and the characteristics of its environment. To achieve this, our analysis will be based on the hypothesis that the decision of a developing country to adopt IFRS is motivated by a specific set of environmental factors in the country that are economic and behavioral only.

\subsection{Economic factors}

One factor that has been widely quoted and strongly associated with the dissimilarities accounting systems study is the economic context. It is clear then that the interrelationships between accounting and economics have much written long ago. We always infer the existence of a link between the structure of the accounting precepts and the economy. This reasoning is based on the idea that economic conditions are always a major determinant of the development of the accounting system of a country. Indeed, economic factors contribute significantly to the explanation of the phenomenon of adoption of international accounting standards.

It was agreed that the development of an accounting system is conditioned by the nature of the economic context (e.g. economic growth, inflation, economic openness to the outside, the degree of freedom to invest etc.) of a country. Considering that the world can be divided into rich and poor countries, Mueller, German and Meek (1987) documented that countries can also be divided into two laps "countries with accounting" and "countries without accounting ".To explain this phenomenon, Alhashim and Arpan (1992) and Cooke and Wallace (1990) suggest that internal as well as external economic factors influence accounting. Thus, the impact of this variable seems so significant and may lead to this hypothesis:

$\mathrm{H} 1$ : Economic factors have an influence on the use of international standards.

In 1968, Mueller called the economic structure; the type of economy and the level of growth, produce other effects on the accounting practices of a country. In connection with the influence of the economic factor was treated extensively in the literature indicating the importance of the pattern of economic growth (Choi, Mueller, 1992).Adhikari and Tondkar (1992) suggested that the level of economic growth of a country has a positive effect on the development of systems and accounting practices. Indeed, in countries where the level of economic growth is relatively high, the social function of accounting, as an instrument of measurement and communication, has a considerable importance. Woolley (1998) found that a high level of economic growth in Asian countries has 
significantly affected the adoption of IFRS. Nobes(1998) and Abdolmohammadi, Rhodes and Tucker (2002) explained that when economic activities reach a certain size of complexity, countries relating there to require a sophisticated accounting system. So the accounting system will undergo major changes in response to the demands of changing economic conditions for a more dynamic business environment. In light of the above, we propose the following sub-hypothesis:

H1.1: The probability that developing countries adopt IFRS increases with economic growth.

Belkaoui (1983) indicated that the level of economic and civil freedom is an essential factor in the development of accounting practices. He insisted that in a country with a low level of freedoms, citizens cannot choose members of the government in a democratic manner. They cannot even conduct an influence on government policies. All things considered, it is inconceivable that these people can successfully create a developed accounting system or create an accounting profession based on the principle of "full and fair disclosure." This effectively and certainly materializes again that a favorable political environment positively influences the development of accounting. Martin Bronfenbrenner (1955) and Amartya Sena (2004) exhibited economic freedom as an economic and political end to different things in different perspectives. In truth, the principal framework for economic freedom rushes classical liberal customs. These last preach free trade, free markets and private property. Stephen T. studies, Easton and Michael A. Walker (1997), Eliezer B. Ayal and Georgios Karras (1998), Niclas Berggren (1999), Minxin Pei (2001) and Gerald Scully (2002) showed that the levels of life and economic growth are positively correlated to the level of economic freedom. These results lead us to enrich our study by the integration of another sub-hypothesis:

H1.2: Developing countries with a high degree of economic freedom are more likely to adopt IFRS.

Cerne (2012) noted that the level of inflation in an economy can also be regarded as an essential component affecting the accounting system of a country, especially as it affects the balance sheet assets assessment method because under conditions of high inflation, it is essential to have an appropriate accounting system. In this context, the third sub hypothesis to be tested is:

H1.3: The level of inflation has a significant influence on the choice of IAS / IFRS by developing countries.

The correlation between financial markets and accounting systems has been analyzed by several studies. In fact, a large financial market with a great and different mass of shareholders requires obviously better production of information. Thus the existence of a financial market is considered one of the key factors in the economic development of a country because of its role in the optimal allocation of resources among different economic sectors and between companies within each sector. (Zeghal, 2006)

Gray, McSwenney and Shaw (1984), insisted on the fact that investors need financial information of quality in order to be able to make the best choices when they analyze investment opportunities. According to Adhikari and Tondkar, (1992), investors can, in some cases, even lead the accounting standard setters from one country to reform its accounting system and likely adopt international accounting standards. In addition, in countries with a financial market, standardization bodies tend to establish sophisticated accounting systems to ensure the provision of quality financial information that will be practically useful to investors in their decisions. In this context, Chamisa (2000) reported that the emergence of financial markets in developing countries such as Zimbabwe has promoted the use towards the adoption of IFRS. A significant link between these markets and the adoption of IFRS has been verified. Gornik-Tomaszewski and Jemakowicz (2006) revealed that countries with financial markets that are open to a mass of foreign investors are more likely to adopt IFRS. In addition, Karamanou and Nishiotis (2005), Kinsey (2006) and Al basteki (2000) also showed that the existence of a glorious financial market in a country largely affects the adoption of IFRS. We, therefore, propose the fourth sub-hypothesis:
H1.4: Developing countries with a developed financial market are more likely to adopt IFRS.

External pulses could also impact on the adoption of international accounting standards. The main forces behind the development and adoption of international standards are foreign investors, multinational companies, international accounting firms and global financial institutions. Cooke and Wallace (1990) conducted a study, promoting the relevance of including external environmental factors in trying to understand the accounting's structuring system. The degree of economic openness to the outside is one of these factors. According to these authors, the more the economy of a country is open to the outside, the more the country is exposed to various international pressures. These pressures could take some developing countries to choose IFRS. Indeed, the influence of economic relations between the countries on the development and design of an accounting system is the result of a developed international exchange. Therefore, the accounting system of a country can be affected by the accounting system of another country because of its geographical position also because the first represents a major export market for the second (Cerne, 2007). In this regard, a fifth sub-hypothesis has also taken place:

H1.5. Developing countries with a high degree of economic openness to the outside are more likely to adopt IFRS.

\subsection{Behavioral factors}

A minority of studies examined the behavioral emblems of the country to the alternative of adoption international accounting standards (IFRS). According to the schools adopting the behavioral sciences; the determinants of the human behavior are individual, social and cultural. Indeed, humans perceive different ways of contractions, according to the environment in which it is immersed, according to his precept of personal motivations and according to his abilities. Through a behavioral way, the individual has sake of stability and mutation that will enable him or not to improve the profitability of any choice as that of the adoption of IFRS. The "homo-economicus" design supports that humans are rational; it is simply driven by the gain. So if the hardware suites are directly related to the attentions provided, the individual responds by producing the maximum performance of which he is clever. Therefore, in the context of accounting standards, the entity will move towards these standards except the last one will promote the expected surplus. Using the theory of planned behavior (TPB), Djatej an Al. (2012) studied empirically a wide variety of relevant factors influencing the intention of the early implementation of IFRS in the United States.

These factors include attitude, subjective norm and perceived control arising from the design of Ajzen's planned behavior (1991). Their results suggest that the perceived subjective and control standards have a significant influence on early intentions of the adoption of IFRS. Thus, we can set up our second hypothesis:

$\mathrm{H} 2$ : Behavioral factors influence the use of international accounting standards.

The difficulty of measuring the variables explaining human behavior led us to diversify the weights to better detect the efficiency of this factor in the adoption of international accounting standards. The selected variables are: the overall level of innovation, the internal level of peace, the index of corruption's perception, the existence of good governance practice guidelines and the level of likelihood of violent protests. SY (2012), in a study that examined the relationship between ownership of IAS / IFRS and dimensions of organizational and managerial accounting, was largely recommended that the implementation of IFRS is the result of managerial innovation. This author also showed that the IFRS accounting practices are spreading rapidly by the phenomenon of isomorphism, by imitation or discursive coercively (DiMaggio and Powell, 1983). Given the foregoing, the first sub-hypothesis to be tested is:

H2.1: The probability that developing countries adopt IFRS is significantly related to its level of innovation. 
Hazhar (2010) mentioned, in a study on a sample of developing countries, that there is a problem of environmental origin of the countries that could adopt IFRS. Indeed, the security situation could determine whether or not a country adopts.

In this context, the second sub-hypothesis to consider is:

H2.2: the more a country exhibits a high level of internal peace, the more it becomes favorable to the adoption of IAS / IFRS.

Irvine et al. (2006) found that corruption in the United Arab Emirates has significantly contributed to the failure of this nation to adopt IFRS. Following this idea, another hypothesis takes place: H2.3: the index of corruption's perception has a significant effect on the use of international accounting standards.

In light of the foregoing circumstances, the existence of a governance structure based on respected rules and the probability of violent protests may also be included among the behavioral hypothesis of the adoption of IFRS. In this perspective, two other hypotheses remain to be tested are:

H2.4: Developing countries with a governance structure based on rules, in which priority and contract rights are reliably enforced and respected, are more likely to adopt IFRS.

H2.5: The level of violent protest's probability has a significant influence on the choice of IAS / IFRS by developing countries.

\section{Research methodology}

In this section, we discuss our empirical context through the sample selection's procedure, measurement of variables and statistical analysis.

\subsection{Sample and data}

The data for these countries are collected mainly from official websites of the following databases: the World Bank, Freedom House, The Economist, Master Nation, Pew Research Center and the Transparency International "Global Coalition against Corruption." Our initial sample consists of all developing countries that are among 144 countries (according to the list provided by the ISI) which were broking down into 75 countries adopting or planning to adopt IFRS and 69 others that may be far-away from the adoption of these standards. The adopted strategy (adoption, planning to adopt and non-adoption of IFRS) in each country was identified after contacting the IASB. The latter provided a method to detect the strategy of each country to adoption since there is no database defining and classifying those countries into those have adopted or are planning to adopt IFRS and those that have not yet adopted these standards.

The phase of the constitution of our final sample was performed as we have already quoted following a procedure that uses the information found on the official websites of the IASB and that of the World Bank.

- $\quad$ Composing a list of "countries adopting or planning to adopt IFRS for SMEs" was chosen from the IASB's update published in July 2013.

- $\quad$ Detection of the list of countries adopting IFRS "in the Full version or the version for SME or both versions together" was chosen from the official site of IFRS in September 2013.

- $\quad$ Deduction of the final list of countries adopting or planning to adopt IFRS worldwide

- $\quad$ Extraction of the list of developing countries adopting or planning to adopt IFRS (extraction was based on the list of developing countries provided by the ISI in March 2013) and therefore, retain a remaining that represents the developing countries list that did not adopt IFRS. The following table illustrates the constitution of the final sample.

Table 1: Composition of the Final Sample

\begin{tabular}{ll}
\hline Sample & Developing Countries \\
\hline Starting sample & 144 \\
Countries that adopt IFRS in 2013 & 40 \\
The countries where information is not available & 10 \\
Residual & 30 \\
Countries planning to adopt IFRS & 36 \\
Countries where information is not available & 10 \\
Residual & 26 \\
Countries that remain far from adopting IFRS & 68 \\
Countries where information is not available & 48 \\
Residual & 20 \\
Final sample & 76 \\
\hline
\end{tabular}

The following table advances a description of the sample by geographic location.

Table 2: Distribution of the Final Sample by Geographic Place

\begin{tabular}{llll}
\hline $\begin{array}{l}\text { Geographical } \\
\text { location }\end{array}$ & $\begin{array}{l}\text { Number of } \\
\text { countries } \\
\text { adopting IFRS }\end{array}$ & $\begin{array}{l}\text { Number of } \\
\text { countries plan- } \\
\text { ning to adopt } \\
\text { IFRS }\end{array}$ & $\begin{array}{l}\text { Number of } \\
\text { countries that } \\
\text { do not adopt } \\
\text { IFRS }\end{array}$ \\
\hline $\begin{array}{l}\text { Sub-Saharan } \\
\text { Africa }\end{array}$ & 5 & 7 & 12 \\
$\begin{array}{l}\text { East Asia and } \\
\text { Pacific }\end{array}$ & 5 & 2 & 2 \\
$\begin{array}{l}\text { Europe and } \\
\text { Central Asia }\end{array}$ & 9 & 4 & 3 \\
$\begin{array}{l}\text { Latin America } \\
\text { and Caribbean }\end{array}$ & 8 & 8 & 0 \\
$\begin{array}{l}\text { Middle East and } \\
\text { North Africa }\end{array}$ & 0 & 4 & 3 \\
$\begin{array}{l}\text { Southeast Asia } \\
\text { Total }\end{array}$ & 3 & 1 & 0 \\
\hline
\end{tabular}

\subsection{Measuring variables and empirical analysis}

\section{i) The dependent variable}

Analysis of the information found in the accounting systems of selected developing countries in our study allows us to distinguish between countries that have adopted or planning to adopt and those which have not adopted these standards. This distinction allows us to define a dichotomous variable that takes the value 1 if a country has adopted or plans to adopt IFRS and zero if not.

ii) The independent variables

Depending on the specific attributes of each country and the previous accounting studies, the following environmental factors will be tested to explain the use of developing countries to IFRS namely: economic and behavioral factors.

Table 3: Summary of the Independent Variables Measures

\begin{tabular}{lll}
\hline Factors & Variables & Measuring \\
\hline $\begin{array}{l}\text { Economic growth } \\
\text { (EG) }\end{array}$ & $\begin{array}{l}\text { The average of annual growth rate } \\
\text { of gross domestic product (GDP) } \\
\text { during the five years preceding the } \\
\text { date of adoption. }\end{array}$
\end{tabular}

The degree of economic freedom (DEGFREE)

The level of infla-

$\begin{array}{ll}\text { Economic } & \text { tion } \\ \text { (INFL) }\end{array}$

The development of the financial market (MC)

The economic opening to the outside (EO)
The average degree of freedom to invest in the five years preceding the date of adoption.

The average inflation, consumer prices (annual \%) during the five years preceding the date of adoption.

The average market capitalization during the five years preceding the date of adoption.

The average rate of gross foreign direct investment, divided by gross domestic product (GDP) for the five years preceding the date of adoption. 
the overall level of innovation (INNOV)

The average expenditure on research and development (\% of GDP) during the five years preceding the date of adoption.

The internal level of peace

(IP)

The average level of peace within the five years preceding the date of adoption.

The level of cor-

Behavioral ruption

factors (COR)

Compliance with governance rules (GOV)

The level of probability of manifestations (MANIF)
The average index of perception of corruption in the four years preceding the date of adoption.

The average ranking of property rights and governance rules by the CPIA ( $1=$ low to $6=$ high) during the five years preceding the date of adoption.

The average level of probability of violent protests during the five years preceding the date of adoption. iii) The empirical analysis

The purpose of the methodology is the highlighting and analyzing the relationship that may exist between the economic, behavioral and IFRS adoption in developing countries. This research follows a hypothetical-deductive methodology. It tries to confirm or refute the hypotheses. After analyzing the data collected through a descriptive and comparative aspect between the two-sample groups (countries that have adopted IFRS and those planning to adopt vs countries that not adopting IFRS), our research will be based on a multivariate analysis that represents the most interesting phase of the study since it allows assessing the impact of different variables taken together. Before starting this analysis, we will conduct a review of the correlations between the different variables. In case of no detection of a possible multicollinearity between these variables, we can introduce them all to the model.

It should be noted that different statistical tests will be conducted with SPSS 20 software.

Since the dependent variable is binary, that takes 1 if a country has adopted or plans to adopt IFRS; 0 if not, the proper analysis would be an application of logistic regression.

$\log \left(\mathrm{P}_{\mathrm{i}} /\left(1-\mathrm{p}_{\mathrm{i}}\right)\right)=\alpha_{0}+\alpha_{1} \mathrm{EG}_{\mathrm{i}}+\alpha_{2} \mathrm{DEGFREE}_{1}+\alpha_{3} \mathrm{INFL}_{\mathrm{i}}+\alpha_{4} \mathrm{MC}_{\mathrm{i}}$ $+\alpha_{5} \mathrm{EO}_{\mathrm{i}}+\alpha_{6} \mathrm{INNOV}_{\mathrm{i}}+\alpha_{7} \mathrm{IP}_{\mathrm{i}}+\alpha_{8} \mathrm{COR}_{\mathrm{i}}+\alpha_{9} \mathrm{GOV}_{\mathrm{i}}+\alpha_{10} \mathrm{MANIF}_{1}$ $+\varepsilon$

Where:

$\mathrm{P}_{\mathrm{i}}$ : The probability of adoption of IAS / IFRS in 2013.

EG: Economic growth.

DEGFREE: The degree of economic freedom.

INFL: the level of inflation.

MC: Market capitalization.

EO: The economic opening to the outside.

INNOV: the overall level of innovation.

IP: The internal level of peace.

COR: The level of corruption.

GOV: The proper compliance with governance rules.

MANIF: The level of probability of manifestations.

$\alpha_{0}$ : Constant.

i: developing country.

$\alpha_{1}, \alpha_{2}, \alpha_{3}, \alpha_{4}, \alpha_{5}, \alpha_{6}, \alpha_{7}, \alpha_{8}, \alpha_{9}, \alpha_{10}$ : the model's parameters to be estimated.

$\varepsilon$ : the margin of error.

\section{Empirical test and results}

The empirical data will be addressed by using three figures of statistical tools. The first is the descriptive analysis that identifies the overall texture of each variable in developing countries. The second figure is the univariate analysis. This tool will allow us to test the impact of each variable on the adoption of IFRS. The third tool of analysis is the multivariate analysis method. It admits to improve the results of the univariate analysis by other empirical results arrived from the estimation of multivariate regression models.

\subsection{Presentation of the descriptive analysis: characteris- tics of the two groups together}

Given that all independent variables were lacking the dichotomous nature, descriptive analysis is restricted to the presentation only of averages and standard deviations. The results of the descriptive analysis of the variables are presented in the following table:

Table 4: Descriptive Statistics of Independent Variables

\begin{tabular}{|c|c|c|c|c|c|}
\hline Variables & $\mathrm{N}$ & Mean & SD & Min & Max \\
\hline EO & 76 & 4,2663 & 32,29127 & $-10,42$ & 281,54 \\
\hline $\mathrm{MC}$ & 76 & 23,5859 & 34,66552 & 0,01 & 178,49 \\
\hline EG & 76 & 4,1156 & 2,42346 & $-2,45$ & 10,92 \\
\hline INFL & 76 & 7,7487 & 5,52021 & $-0,85$ & 36,82 \\
\hline DEGFREE & 76 & 49,4408 & 17,32801 & 9,00 & 83,00 \\
\hline COR & 76 & 3,3750 & 1,13972 & 1,63 & 7,13 \\
\hline GOV & 76 & 1,3927 & 1,50401 & 0,00 & 3,50 \\
\hline IP & 76 & 2,5226 & 0,46283 & 1,66 & 4,26 \\
\hline MANIF & 76 & 3,1447 & 0,74556 & 1,00 & 5,00 \\
\hline INNOV & 76 & 0,3192 & 0,48997 & 0,00 & 3,55 \\
\hline
\end{tabular}

From the outset, the description of the variables related to the subject of our sample, 76 developing countries have shown the weakness of the indicators on the economic component on one hand and on the behavioral component, on the other. Indeed, if we compare the average level of economic freedom of Luxembourg (degree of freedom $=93$ ) selected for the 2008-2012 period with that of 76 developing countries (degree of freedom $=49.4408$ ), we point out obviously the gap between developing countries and developed countries. Referring to Table 4, we also find that the proportion of foreign direct investment is relatively high in relation to GDP, which is an average of $4.2663 \%$. This robustness can be explained by the strong economic openness in some developing countries such as Mauritius, which reaches a maximum percentage of foreign direct investment compared to the GDP of $281.54 \%$ over the period 2008 to 2012 . This clearly explains the high level of standard deviation of this variable, which is 32.29127 and therefore, reflects the net dispersion across countries (Liberia shows the average minimum is $-10.42 \%$ ). This result is similar to the market capitalization which reveals a standard deviation of 34.66552 resulting from the highest average percentage of market capitalization compared to South Africa's GDP, which is $178.49 \%$ (North Korea presents the minimum average is $0.01 \%$ ). It should also be noted that economic growth and inflation have been average $(4.1156 \%$ and 7.7487 respectively) that reproduce well the reactionary character of developing countries. Regarding to behavioral attributes, variables have, in most cases, low standard deviations. This signals the uniformity of behavior and attitudes of people in the developing countries. A primary analysis of different behavioral variables reveals that developing countries are very close, especially at the level of internal peace that has a standard deviation of 0.46283 . Indeed, according to the Global Peace Index which has a scale of 1 to 5 (high-low). The results of our research indicate an average of 2.5226 , which reveals a middling level of internal peace in developing countries. It may be noted also that the probability's level of violent manifestations, similarly classified that the level of internal peace through Global Peace Index, is correspondingly high in developing countries. The average over the period from 2009 to 2012 is 3.1447 .

In addition, it is essential to say that corruption in the public sector is widely spread in developing countries (an average of 3.3750 over the period 2009-2012). In fact, this index was established by International Transparency (IT) which provides on a scale of 0-10 a score of perceived corruption in the public sector in each country, where 0 means that the country is perceived as highly corrupt and 
10 means that the country is perceived as very clean. The level of compliance with governance rules, a measure identified by the World Bank, reveals an average of 1.3927 for the period 2008 2012 which is strictly very low if we refer to the scale of this score ( $1=$ low to $6=$ high). Regarding this variable, it should be noted that developing countries are partially homogeneous (a standard deviation of 1.50401) in relation to proper compliance with governance rules.

In addition, the overall level of innovation in developing countries is ample stored as low (an average of $0.3192 \%$ for the period 2006-2010) when we compared with that of Sweden in 2010 that traces a level of $3,39902 \%$.

\subsection{Results of univariate analysis: comparison between the two groups of countries}

The purpose of this analysis is to examine whether there is a difference between the group of developing countries which have adopted or are planning to adopt IFRS and the group of countries that have not yet adopted these standards. To achieve this, a comparison test of means between two independent samples should be taken. The normality test of Kolmogorov-Smirnov (Appendix 1) allowed us to identify the most appropriate technique to access the comparison of means. Indeed, if the distribution of a variable follows the normal distribution, the Student $t$ test is the appropriate technique to compare means between the two groups of countries; if not the Mann Whitney test using the order of the observations of the two samples would be more suitable. The parametric Student test (Table 5) was applied to compare the means of economic growth, the degree of economic freedom and the level of internal peace while the other variables will be treated with the Mann Whitney test (see table 6).

Table 5: Comparison between the Two Groups of Developing Countries: Student's T Test

\begin{tabular}{llllllll}
\hline \multicolumn{7}{c}{ Statistics of two groups } \\
Variables & Adopt & Mean & SD & F & *Sig. & t & Sig. \\
\hline \multirow{2}{*}{ EG } & Adoption & 3,826 & 2,456 & & & & \\
No & 4,924 & 2,185 & 0,084 & 0,77 & $-1,764$ & 0,082 \\
DEGFREE & $\begin{array}{c}\text { Adoption } \\
\text { Adoption } \\
\text { No }\end{array}$ & 52,678 & 17,450 & & & & \\
& $\begin{array}{c}\text { Adoption } \\
\text { Adoption } \\
\text { IP }\end{array}$ & 40,375 & 13,650 & 1,632 & 0,21 & 2,852 & $0,006 * *$ \\
& $\begin{array}{c}\text { No } \\
\text { Adoption }\end{array}$ & 2,602 & 0,456 & & & & \\
\hline ** Significant at the 5\%; * Levene's test for equality of variances &
\end{tabular}

Through the comparison of means, we find that countries that have adopted or are planning to adopt IFRS are characterized by a high degree of economic freedom (52.6786\%) compared to other developing countries $(40.3750 \%)$. this difference is significant profusely at the conventional threshold of $5 \%$. This is consistent with what is provided in our hypothesis. In contrast, economic growth and the level of internal peace show strong averages in countries that have not adopted IFRS.

Since the dissimilarity of these variables between the two groups (EG and IP) is not significant, we can implicitly anticipate that our hypothesis are relatively confirmed.
Table 6: Comparison between the Two Groups of Developing Countries: Mann Whitney U Test

\begin{tabular}{lllll}
\hline \multirow{2}{*}{ Variables } & ADOPT & Average rank & Z & Sig. \\
\hline \multirow{2}{*}{ EO } & Adoption & 40,38 & $-1,238$ & 0,215 \\
& No Adoption & 33,25 & & \\
MC & Adoption & 43,02 & $-3,053$ & $0,002^{*}$ \\
& No Adoption & 25,85 & & \\
INFL & Adoption & 39,68 & $-0,778$ & 0,436 \\
& No Adoption & 35,20 & & \\
COR & Adoption & 43,14 & $-3,066$ & $0,002^{*}$ \\
\multirow{2}{*}{ GOV } & No Adoption & 25,50 & & \\
& Adoption & 37,69 & $-0,564$ & 0,572 \\
MANIF & No Adoption & 40,78 & & \\
& Adoption & 37,04 & $-0,971$ & 0,331 \\
\multirow{2}{*}{ INNOV } & No Adoption & 42,58 & & \\
& Adoption & 42,13 & $-2,404$ & $0,016^{*}$ \\
\hline
\end{tabular}

* Significant at the $5 \%$

In light of the results presented in Table 6 above, we notice that there is a clear difference between the group of countries that have adopted or are planning to adopt IFRS and the group of countries that have not yet adopted these standards. Indeed, the degree of economic openness, the proportion of market capitalization to GDP, the level of corruption and the overall level of innovation have culminating values in the countries adopting or planning to adopt IFRS, especially the market capitalization of the group that has adopted or plans to adopt IFRS which in excess of about $40 \%$ $(39.91 \%)$ other countries in the sample. It should be noted that only the differences in variables (INNOV), (MC) and (COR) are significant at the 5\% level. These ranges are adapted to our hypothesis only for variables (MC) and (INNOV).

Nevertheless, the results in Table 6 exhibited a large gap between the two groups of developing countries in the sense that countries that have not adopted IFRS have the highest average. These have shown that the level of inflation in the first group (the countries that have adopted or are planning to adopt IFRS) is greater than the second group, but with a difference that is devoid of significance $(\mathrm{sig}=0.436)$ at the $5 \%$ level. The empirical outcomes of the variable representative the level of compliance with the rules of governance (GOV) is similar to those of the variable (INFL). The corresponding relations of these two variables are the same as provided in our hypothesis. The level of violent protests in the second group (the countries that have not adopted IFRS) also reveals an average that is higher than that of other developing countries. Out of hand, this is in line with our expectations; however, given the lack of significance in this difference, the hypothesis for this variable is rejected.

Based on univariate analysis, we have determined on one hand, that developing countries adopting or planning to adopt IFRS contain the lowest levels of inflation and reveal the highest levels of: economic growth, degree of economic freedom, internal peace, and the proportion of market capitalization to GDP, the overall level of innovation and respect the rules of government, on the other.

\subsection{Multivariate analysis}

The target of this analysis is to test the simultaneous impact of all explanatory variables and discern the validity of theoretical concepts. The model to be tested is a logistic regression model. To estimate the parameters of this regression, it was commonly used a technique which is not that of ordinary least square but the maximum likelihood technique. This method is based on an iterative algorithm because of the nonlinear quality of the regression. It seeks to maximize the log likelihood that broadcasts how the observed values of the dependent variable can be predicted from the observed values of the explanatory variables. Applying logistic regression usually solicits the absence of multicollinearity between the independent variables. This phenomenon can be guessed, one hand, by the analysis of the Pearson correlation matrix and, secondly, by the test VIF (Variance Inflation Factor) 
available in SPSS. The outcomes of these tests, as set out in Appendix 2, reveal that the correlation coefficients are significantly smaller than 0.8, which is the limit traced by Kennedy (1985) and that the FIV tests are well less than 3. Therefore, the correlation between the explanatory variables does not have a constraint. Our approach is firstly, to assess from Table 7 the overall characteristics of the logistic model and to partially analyze it in order to check our hypothesis on the other hand.

Table 7: Results of the Logistic Regression

\begin{tabular}{llll}
\hline Variables & Coeff $\alpha$ & Wald & Sig. \\
\hline EO & 0,589 & 3,162 & 0,075 \\
MC & 0,009 & 0,160 & 0,689 \\
EG & $-0,155$ & 0,978 & 0,323 \\
INFL & 0,144 & 3,026 & 0,082 \\
DEGFREE & 0,054 & 3,385 & 0,066 \\
COR & $1,679 *$ & 4,992 & 0,025 \\
GOV & 0,090 & 0,120 & 0,729 \\
IP & 0,535 & 0,255 & 0,613 \\
MANIF & 0,694 & 1,347 & 0,246 \\
INNOV & 0,118 & 0,008 & 0,928 \\
Khi-deux & $28,303 *$ & & \\
-2Log-Likelihood & 59,300 & & \\
Hosmer-Lemeshow test & $10,647 *$ & & \\
R-square of Cox \&Snell & 0,311 & & \\
R-square of Nagelkerke & 0,454 & & \\
$\%$ of good classification of the model & 80,3 & & \\
N & 76 & & \\
\hline * The probability is significant on level of 0.05 & & & \\
\end{tabular}

The testing of the model evaluation parameters that are shown in the table above, commits us to infer that this model has a good overall significance (significant at the 5\% to reject the null hypothesis that the coefficients ( $\alpha$ ) are all equal to zero), an acceptable explanatory power (R-square of Cox \&Snell and R-square of Nagelkerke) and better quality of the data's adjustment (-2logLikelihood, the Hosmer-Lemeshow).

Furthermore, the model can also be judged correct through its predictive ability. The latter is detected from the classification table (SPSS 20). This table admits to cross the different forms of the observed variables with those expected. The cells on the diagonal represent the correct estimates when the off diagonal cells represent incorrect estimates. This table allows us to generate a classification model that percentage is around $80.3 \%$. Indeed, the model was able to correctly classify $80.3 \%$ of the sample. So, it traces a good predictive quality given to the logistic regression. The analysis partial of the model will be according to the independent variables mentioned in the logistic function. First of all, we note that the majority of the factors do not have significantly affected the decision to adopt the IFRS. Indeed, corruption appears to be the only variable that widely and significantly affect the decision to adopt IFRS by developing countries (coefficient $=$ 1.679 , Sig $=0.025)$. This result confirms our hypothesis $(\mathrm{H} 2.3)$ of the study, but also the statements of abstraction environmental factors in the adoption of IFRS by developing countries. However, the result joined to economic growth has put the claims of previous studies (Choi, Mueller, 1992; Adhikari and Tondkar 1992; Woolley, 1998; Nobes, 1998; Abdolmohammadi, Rhodes and Tucker, 2002; Zeghal et al, 2006), concerning its magnitude in the decision to adopt international accounting standards, in subsidence. Hence, the hypothesis (H1. 1) is completely reversed. Although the positive sign of the coefficient of economic openness $(\mathrm{OE})$ was consistent with our expectations and represents the most robust economic factor (coefficient $=0.589$ ). This variable does not appear to be fatal in determining the decision of IFRS adoption $(\mathrm{Sig}=0.075)$. To this end, our hypothesis (H1. 5) is partially confirmed. The results also indicate that despite the relative significance of the degree of economic freedom and market capitalization, our hypothesis (H1. 2) and (H1. 4) are proportionally certified. In fact, developing countries with a high degree of economic freedom and more developed financial markets seem most likely to adopt IFRS. The non-significance of these variables can be justified by the youth of the majority of the financial markets as well as attempts pushing the extent to invest in developing countries.

Hypothesis (H1. 3) on the level of inflation is partially rejected. Indeed, the level of inflation gratifies a positive influence, but not a significant influence on the choice of IAS / IFRS by developing countries. These results are significantly contradictory to those of Cerne (2012). For other factors of behavioral attribute, the level of violent protests is the strongest variable (coefficient $=0.694$ ) that affects the decision to adopt IFRS in developing countries. This confirms imperfectly $(\mathrm{Sig}=0.246)$ the hypothesis $(\mathrm{H} 2.5)$. Empirical analysis brought by this variable can be explained by the decline of multinational firms, which requires the adoption of highquality standards, including IFRS, to locate in countries with unstable environment. The results attached to variables (GOV) and (IP) have completely contradicted the hypothesis (H2. 4) and $(\mathrm{H} 2.2)$. The level of internal peace and the degree of compliance with government rules do not seem to be unavoidable factors claiming the decision to adopt IFRS in developing countries. Indeed, these variables hold ample insignificant coefficients (Sig = 0.729 and 0.613 respectively). Regarding to the level of innovation, the variable (INNOV) showed a positive and a largely insignificant coefficient $(\mathrm{sig}=0.928)$ on the decision to adopt IFRS by developing countries. Therefore, this result reverses approximately our hypothesis $(\mathrm{H} 2.1)$ which indicated the probability that a developing country will adopt IFRS is significantly and positively related to its level of innovation. The non-significant effect of this variable can be interpreted by the week and the strong dispersion of levels of innovation in developing countries.

Consequently, it is obvious that the results of the multivariate analysis are largely different from those of the univariate analysis. It turns out that behavioral factors, (corruption is the strongest factor) are more dominant than economic factors in the decision to adopt IFRS by developing countries.

\section{Conclusion}

During the last decade, numerous incidents have approached the global economic sphere. In fact, the circumstances that have had major effects on the direction of international business, including financial scandals of the 2000s in Europe and the United States. Their impact has strengthened control and they craved a new wave of transformation of the accounting rules to restore trust with accounting information quality. IFRS constituted then the appropriate refuge for companies that finance themselves increasingly on foreign markets and have suffered for a long time the high cost of adjustments to their accountants to make them comparable and understandable to readers. While a majority of developed countries have been entangled profusely in the movement of the implementation of accounting systems that reflect the attributes of their environment, a minority of developing countries seem to be directed to the adoption of these systems. Therefore, this study aimed to understand the impact of main economic and behavioral factors that may affect the decision to adopt IFRS by developing countries. In other words, we have looked to identify the different economic and behavioral variables that are potentially able to influence the adoption of IFRS in those countries.

Based on a logistic regression for a sample of 76 developing countries, empirical results showed that corruption is the only factor that is positively and significantly related to the decision to adopt IFRS. However, no significant relationship was found between the other variables in the model and the decision to adopt IFRS in developing countries.

Taken together, the interactions between economic and behavioral factors have shown the robustness of the behavioral attribute in the decision to adopt IFRS in developing countries. This work allowed saying that developing countries with high corruption perception index are more likely to be adopted or plan to adopt IFRS. The significant effect of corruption emphasizes that the use of IFRS is only a kind of refuge and escape from the impact of different institutional abuse of a country including corruption. This 
has also allowed us to conclude that the decision to adopt IFRS by developing countries does not reflect a logical action and a perfect agreement with the reality of a nation. It usually stems from a desire for legitimacy on the part of these countries in the international community.

These results are consistent with studies that have tirelessly demonstrated that organizations do not necessarily select the most appropriate technicalities to the needs and economic demands of the moment, but those accepted socially. This isomorphism is only a consequence of reasoning which reflects a given behavior. Our results are important for local accounting organizations of the selected countries in our sample since they can provide better discernment of the factors that can encourage the adoption of IFRS.

However, it is essential to specify that certain limits are allocated to our study. They are attached, mainly to the restriction of the model's variables around two aspects (economic and behavioral) in abstraction of other variables that are widely adopted in the literature including political and cultural factors. This made a model containing several non-significant variables.

Since the sample of the study is considerably very heterogeneous and displays an important mass of countries, it should in future research to be focused on a study by country or a group of countries tracing a homogeneous specificities in order to better refine the results. Other forthcoming work appears also conceivable to answer the following problems: What are the real factors which are in favor or against the adoption of the IFRS in the developing countries?

\section{References}

[1] Abdolmohammadi, Rhodes M, Tucker J (2002), The influence of accounting and auditing on a country's economic development, Re view of Accounting and Finance 1, 42-53. http://dx.doi.org/10.1108/eb026990.

[2] Abrahamson E (1996), Management fashion, Academy of Manage ment Review 21, 254 - 285.

[3] Adhikari A, Tondkar R H (1992), Environmental factors influencing accounting disclosure requirements of global stock exchanges, Jour nal of International Financial Management and Accounting 4 , 75105. http://dx.doi.org/10.1111/j.1467-646X.1992.tb00024.x

[4] Ajzen I (1991), the theory of planned behavior, Organizational Be havior and Human Decision Processes 50, 179-211. http://dx.doi.org/10.1016/0749-5978(91)90020-T.

[5] Al basteki H (2000), Strategies for enhancing the accounting profession and practices in Bahrain: Accounting experts' perceptions, Re search in accounting in emerging economies 4, 165-189.

[6] Alhashim D, Arpan J (1992), International Dimensions of Accounting, PWS-Kent Publishing Company 2ème edition, Boston.

[7] Al-Rai Z, Dahmash N (1998), The effects of applying international accounting and auditing standards to the accounting profession in Jordan, Advances in International Accounting 1, 179-93.

[8] Amartya S (2004), Rationality and Freedom, pp. 9.

[9] Bamberger I(1988), Stratégies et structures : une analyse de leurs relations dans la perspective des nouveaux développements en théorie stratégique, Economies et Sociétés 8 ,7-23.

[10]Belkaoui A (1983), Economic, political and civil indicators and reporting and disclosure adequacy: Empirical investigation, Journal of Accounting and Public Policy 2, 207-219. http://dx.doi.org/10.1016/0278-4254(83)90025-X.

[11]Belkaoui A, Maksy M (1985), Welfare of the common man and accounting disclosure adequacy: An empirical investigation, The International Journal of Accounting Education and Research 20, 81-94.

[12]Briston R (1990), Accounting in developing countries: Indonesia and The Solomon Islands as case studies for regional co-operation, Research in Third World Accounting 1,195-216.

[13]Carlson P (1997), Advancing the Harmonization of International Accounting Standards: Exploring an Alternative Path, université d' Illinois.

[14]Černe K (2007), Perspektive hrvatskog računovodstvenog sustava u menunarodnoj računovodstvenoj harmonizaciji, magistarski rad.

[15]Cerne K (2012), Influental factors of country's accounting system development, Pregledni rad review, UDK 1, 675-712.

[16]Chamisa E (2000), The relevance and observance of the IASC standards in developing countries and the particular case of Zimbabwe, The
International Journal of Accounting 35 ,267-286. http://dx.doi.org/10.1016/S0020-7063(00)00049-2.

[17]Choi FD, Mueller GG (1992), International accounting, $2^{\text {nd }}$ edition, Englewood Cliffs, NJ: Prentice Hall.

[18]Choi FD, Mueller GG (1984), International accounting. $2^{\text {nd }}$ edition. Englewood Cliffs, NJ: Prentice Hall.

[19]Cooke TE, Wallace RSO (1990), the diagnosis and resolution of emerging issues in corporate disclosure practices, Journal of accounting and business research 20,143-151.

[20] DaCosta R C, Bourgeois JC, Lawson WM (1978), A classification of international financial accounting practices, The International Journal of Accounting Education and Research 13, 73-85.

[21]DiMaggio PJ, Powell WW (1983), The Iron-Cage Revisited: institutional isomorphism and collective rationality in organizational field, American sociological review $48,147-160$. http://dx.doi.org/10.2307/2095101.

[22] Djatej, Zhou, Gorton, McGonigle (2012), Critical factors of IFRS adoption in the US: an empirical study, Journal of Finance and Accountancy 1:9.

[23]Eliezer B, Ayal, Georgios Karras (1998), Components of economic freedom and growth: an empirical study, Journal of Developing Areas Western Illinois University 32, 327-338.

[24]Enthoven A (1973), Accounting and Economic Development Policy, Research in Accounting Conference, Amsterdam

[25]Frank WG (1979), an empirical analysis of international accounting principles, Journal of Accounting Research 17, 593-605. http://dx.doi.org/10.2307/2490520.

[26]Gerald Scully (2002), Economic Freedom, Government Policy, and the Trade-Off between Equity and Economic Growth. Public Choice, Kluwer Academic Publishers 113, 77-96. http://dx.doi.org/10.1023/A:1020308831424.

[27] Gernon H, Meek G, Mueller G. (1987), Accounting: An International Perspective Homewood, IL: Irwin.

[28]Ginsberg A, Venkatraman N (1985), Contingency perspectives of organizational strategy: a critical review of the empirical research, Acad Manage Rev 10, 421-434.

[29] Gray SG, McSwenney LB, Shaw JC (1984), Information Disclosure and the Multinational Corporation, John Wiley and Sons. London.

[30]Hambrick DC, Lei D (1985), toward an empirical prioritization of contingency variables for business strategy, Academy of Management Journal 28, 763-788. http://dx.doi.org/10.2307/256236.

[31]Hannan M, Freeman J (1977), the population ecology of organizations, $\begin{array}{lllll}\text { American Journal of } & \text { Sociology } & 82, & 12 .\end{array}$ http://dx.doi.org/10.1086/226424

[32] Hassab Elnaby HR, Epps RW, Said AA (2003), The Impact of Environmental Factors on Accounting Development: An Egyptian Longitudinal Study, Critical Perspectives on Accounting 14, 273 -292. http://dx.doi.org/10.1006/cpac.2002.0530.

[33] Hassain M, Islam MM, Gunasekaran A, Maskooki K (2002), Accounting standards and practices of financial institutions in GCC countries, Managerial Auditing Journal 17, 350-362. http://dx.doi.org/10.1108/02686900210437453.

[34] Hassan N (1998), the impact of socio-economic and political environment on accounting system preferences in developing economies, Advances in International Accounting 1, 43-88.

[35] Irvine HJ, Lucasy N (2006), the globalization of accounting standards: the case of the United Arab Emirates, Faculty of Commerce.

[36] Jermakowicz EK, Gornik-Tomaszewski S (2006), Implementing IFRS from the perspective of EU publicly traded companies, Journal of International Accounting, Auditing and Taxation 15,170-196. http://dx.doi.org/10.1016/j.intaccaudtax.2006.08.003.

[37] Karamanou I, Nishiotis G (2005), the valuation effects of firm voluntary adoption of International Accounting Standards, University of Cyprus Working Paper.

[38]Kinsey P (2006), Developing countries converging with developed country accounting standards: Evidence from South Africa and Mexico,The international journal of accounting $41,141-162$. http://dx.doi.org/10.1016/j.intacc.2006.04.007.

[39]Larson R (1993), International accounting standards and economic growth: an empirical investigation of their relationship in Africa. Research in Third World Accounting 2, 27-43.

[40]Lawrence PR, Lorsch JW (1967), Organization and Environment: Managing Differentiation and Integration. Graduate School of Business Administration, Harvard University. Boston.

[41] Martin Bronfenbrenner (1955), Two Concepts of Economic Freedom, Ethics 65, 157-170. http://dx.doi.org/10.1086/290998.

[42] Miller IW, Norman WH (1986), Persistence of depressive cognitions within a subgroup of depressed inpatients, Cognitive Therapy and Research 10,211-224. http://dx.doi.org/10.1007/BF01173726. 
[43]Mintzberg (1989), the design school: reconsidering the basic premises of strategic management. Strateg Manage 11,171-95. http://dx.doi.org/10.1002/smj.4250110302.

[44] Minxin Pei (2001), Democracy, Market Economics, and Development, World Bank Publications, "Political Institutions, Democracy, and Development ».

[45] Mir M, Rahamen, AS (2004), the adoption of international accounting standards in Bangladesh: An exploration of rationale and process, Accounting, Auditing \& Accountability Journal 18, 816-841.

[46] Mirghani M (1998), the development of accounting standards in the kingdom of Saudi Arabia: an international accounting standards perspective, Advances in International Accounting 1, 195-206.

[47] Mueller GG (1968), Accounting principles generally accepted in the United States versus those generally accepted elsewhere, The International Journal of Accounting Education and Research 3, 91- 103.

[48] Mueller GG (1967), International Accounting. Macmillan, New York

[49]Nair, RD, Frank WG (1980), the impact of disclosure and measurement practices on international accounting classifications, The Accounting Review 55, 426-450.

[50]Niclas Berggren (1999), Economic Freedom and Equality: Friends or Foes?, Public Choice, Kluwer Academic Publishers 100, 203-223. http://dx.doi.org/10.1023/A:1018343912743.

[51]Nobes C (1998), towards a general model of the reasons for international differences in financial reporting, Abacus 34,162-185. http://dx.doi.org/10.1111/1467-6281.00028.

[52] Perera M (1989), Accounting in developing countries: a case for localised uniformity, The British Accounting Review 21, 141-58. http://dx.doi.org/10.1016/0890-8389(89)90193-5.

[53] Points R, Cunningham R (1998), the application of international accounting standards in transitional societies and developing countries, Advances in International Accounting 1, 3-16.

[54]Porter ME (1980), Competitive strategy. Free Press. New York.

[55]Previts G J (1975), on the subject of methodology and models for international accounting, The International Journal of Accounting Education and Research 10, 1-12.
[56]Radebaugh LH (1975), Environmental factors influencing the development of accounting objectives, standards and practices in Peru, The international Journal of Accounting Education and Research 11, 3956

[57]Samuels J (1990), International accounting standards in The Third World: a synthesis of six articles, Research in Third World Accounting 2, 19-25.

[58] Samuels J, Oliga J (1982), Accounting standards in developing countries, International Journal of Accounting Education and Research 18, 69-88.

[59]Seidler LJ (1967), International accounting-The ultimate theory course, The Accounting Review 42,775-781.

[60] Sharif, Hazhar P (2010), Factors affecting on the Adoption of International Financial Reporting Standards: Iraqi Evidence, Master's Thesis, Universiti Utara Malaysia.

[61] Stephen T ,Easton, Michael A, Walker (1997) ,Income, growth, and economic freedom, American Economic Review, American Economic Association 87, 328-332.

[62] Sy IT (2012), Étude des liens entre l'appropriation des normes IAS/IFRS et les dimensions organisationnelles et managériales des services comptables, LIPSOR (Laboratoire d'Investigation en Prospective Strategie et Organisation).

[63] Wallace R, Briston R (1993), Improving the accounting infrastructure in developing countries, Research in Third World Accounting 2: 20124.

[64] Woolley R (1998), International accounting standards and economic growth, an empirical investigation of their relationship in Asia, Cahier de recherche, School of Accounting and Law, RMIT, Australia

[65]Zeghal D, Mhedhbi K (2006), an Analysis of the Factors Affecting the Adoption of International Accounting Standards by Developing Countries. The international Journal of Accounting 41,373-386. http://dx.doi.org/10.1016/j.intacc.2006.09.009.

\section{Appendix 1}

\begin{tabular}{|c|c|c|c|c|c|c|}
\hline \multicolumn{7}{|c|}{ Normality tests } \\
\hline \multirow{2}{*}{ Variables } & \multicolumn{3}{|c|}{ Kolmogorov-Smirnov } & \multicolumn{3}{|l|}{ Shapiro-Wilk } \\
\hline & Statistics & ddl & Sig & Statistics & ddl & Significance \\
\hline $\mathrm{EO}$ & 0,457 & 76 & 0,000 & 0,125 & 76 & 0,000 \\
\hline MC & 0,248 & 76 & 0,000 & 0,713 & 76 & 0,000 \\
\hline EG & 0,089 & 76 & 0,200 & 0,985 & 76 & 0,504 \\
\hline INFL & 0,151 & 76 & 0,000 & 0,809 & 76 & 0,000 \\
\hline DEGFREE & 0,069 & 76 & 0,200 & 0,984 & 76 & 0,452 \\
\hline $\mathrm{COR}$ & 0,147 & 76 & 0,000 & 0,898 & 76 & 0,000 \\
\hline IP & 0,088 & 76 & 0,200 & 0,966 & 76 & 0,039 \\
\hline MANIF & 0,143 & 76 & 0,001 & 0,967 & 76 & 0,042 \\
\hline INNOV & 0,258 & 76 & 0,000 & 0,600 & 76 & 0,000 \\
\hline
\end{tabular}

\section{Appendix 2}

\begin{tabular}{|c|c|c|c|c|c|c|c|c|c|c|c|}
\hline \multicolumn{11}{|c|}{ Correlations } & \multirow{2}{*}{ VIF } \\
\hline Variables & $\mathrm{EO}$ & $\mathrm{MC}$ & EG & INFL & DEGFREE & COR & GOV & IP & MANIF & INNOV & \\
\hline EO & 1 & & & & & & & & & & 1,106 \\
\hline $\mathrm{MC}$ & 0,143 & 1 & & & & & & & & & 1,382 \\
\hline EG & $-0,017$ & $-0,037$ & 1 & & & & & & & & 1,224 \\
\hline INFL &,- 104 & $-0,147$ & 0,123 & 1 & & & & & & & 1,429 \\
\hline DEGFREE & $233^{*}$ & 0,055 & $-0,271 *$ & $-0,498 * *$ & 1 & & & & & & 2,254 \\
\hline COR & 0,218 & $0,344 * *$ & $-0,139$ & $-0,336^{* *}$ & $0,616^{* *}$ & 1 & & & & & 2,751 \\
\hline GOV & $-0,120$ & $-0,366^{* *}$ & $0,339 * *$ & 0,029 & $-0,223$ & $-0,369 * *$ & 1 & & & & 1,573 \\
\hline IP & $-0,187$ & $-0,027$ & 0,011 & 0,134 & $-0,316^{* *}$ & $-0,512 * *$ & 0,010 & 1 & & & 1,829 \\
\hline MANIF & $-0,183$ & $-0,146$ & 0,073 & 0,033 & $-0,307 * *$ & $-0,484 * *$ & $0,254^{*}$ & $0,535 * *$ & 1 & & 1,636 \\
\hline INNOV & 0,025 & $0,242 *$ & $-0,121$ & $-0,037$ & 0,077 & $0,340 * *$ & $-0,281 *$ & $-0,273^{*}$ & $-0,209$ & 1 & 1,268 \\
\hline
\end{tabular}

